
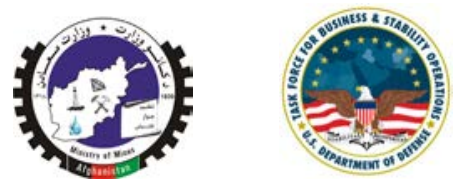

Prepared in cooperation with the Afghan Geological Survey under the auspices of the U.S. Department of Defense Task Force for Business and Stability Operations

\title{
Reconnaissance Investigation of the Placer Gold Deposits in the Zarkashan Area of Interest, Ghazni Province, Afghanistan
}

By Katherine C. Malpeli, Peter G. Chirico, and Isabel H. McLoughlin

Open-File Report 2013-1179

USGS Afghanistan Project Product No. 185

U.S. Department of the Interior

U.S. Geological Survey 


\section{U.S. Department of the Interior \\ SALLY JEWELL, Secretary}

\section{U.S. Geological Survey \\ Suzette M. Kimball, Acting Director}

U.S. Geological Survey, Reston, Virginia: 2013

For more information on the USGS-the Federal source for science about the Earth, its natural and living resources, natural hazards, and the environment-visit http://www.usgs.gov or call 1-888-ASK-USGS

For an overview of USGS information products, including maps, imagery, and publications, visit http://www.usgs.gov/pubprod

To order this and other USGS information products, visit http://store.usgs.gov

Suggested citation:

Malpeli, K.C., Chirico, P.G., and McLoughlin, I.H., 2013, Reconnaissance investigation of the placer gold deposits in the Zarkashan Area of Interest, Ghazni Province, Afghanistan: U.S. Geological Survey Open-File Report 2013-1179, 12 p., http://pubs.usgs.gov/of/2013/1179.

Any use of trade, firm, or product names is for descriptive purposes only and does not imply endorsement by the U.S. Government.

Although this information product, for the most part, is in the public domain, it also may contain copyrighted materials as noted in the text. Permission to reproduce copyrighted items must be secured from the copyright owner. 


\section{Contents}

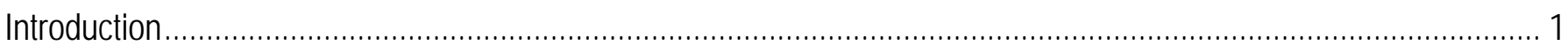

Study Area

Geology

Zarkashan $\mathrm{AOI}$

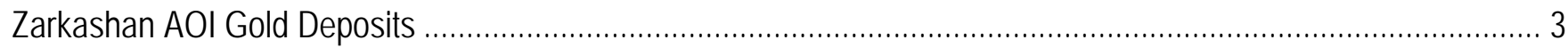

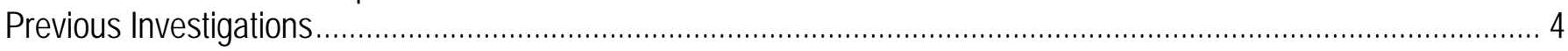

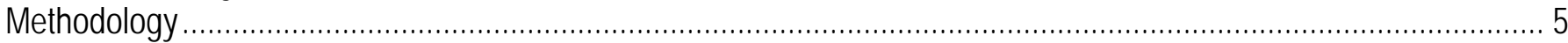

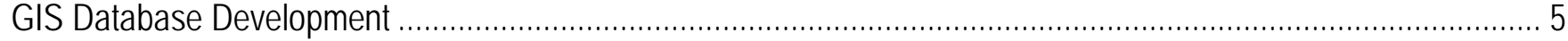

Hydrologic Analysis and Geomorphic Model................................................................................. 5

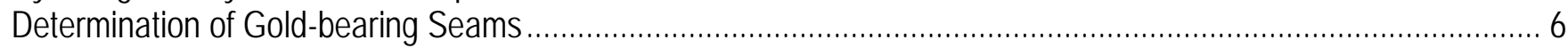

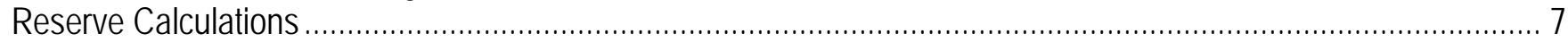

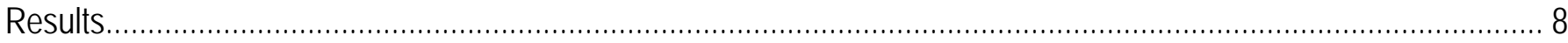

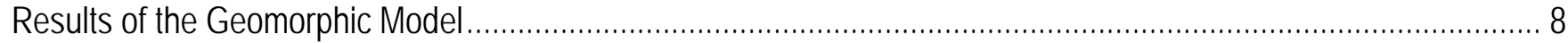

Results of the Gold Seam Reinterpretation

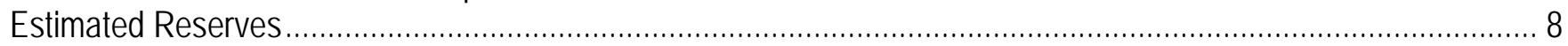

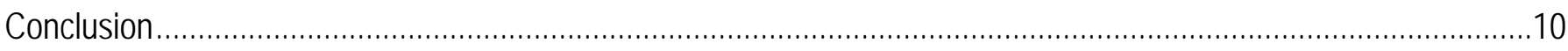

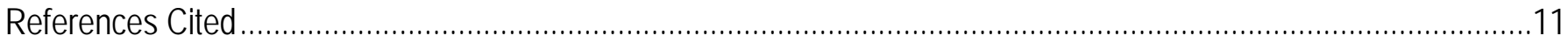

\section{Figures}

1. Map showing location of the Zarkashan $\mathrm{AOI}$ and the Zarkashan mine subarea, the Bolo gold subarea, and the Luman-Tamaki gold subarea.

2. Maps of the central part of the Zarkashan AOI showing geologic and geomorphic units, gold occurrences, gold sampling from previous investigations, and boundaries of potentially auriferous watersheds.

3. Map showing the potentially auriferous and potentially highly auriferous watersheds in the central part of the Zarkashan AOI.

4. Profile of the four newly interpreted gold-bearing seams along the Zarkashan River. ................................... 7

\section{Tables}

1. Results of the volume and grade approach, calculated for each of the four newly interpreted gold-bearing seams.

2. Total number of gold grains sampled during previous investigations within each of the potentially auriferous and potentially highly auriferous watersheds in the central part of the Zarkashan AOI. 


\section{Conversion Factors}

\begin{tabular}{lcl}
\hline \multicolumn{1}{c}{ Multiply } & \multicolumn{1}{c}{ By } & \multicolumn{1}{c}{ To obtain } \\
\hline millimeter $(\mathrm{mm})$ & Length & \\
meter $(\mathrm{m})$ & 0.03937 & inch (in.) \\
kilometer $(\mathrm{km})$ & 3.281 & foot (ft) \\
meter $(\mathrm{m})$ & 0.6214 & mile (mi) \\
\hline & 1.094 & yard $(\mathrm{yd})$ \\
\hline square meter $\left(\mathrm{m}^{2}\right)$ & Area & \\
square kilometer $\left(\mathrm{km}^{2}\right)$ & 10.76 & square foot $\left(\mathrm{ft}^{2}\right)$ \\
\hline & 0.3861 & square mile $\left(\mathrm{mi}^{2}\right)$ \\
\hline cubic meter $\left(\mathrm{m}^{3}\right)$ & Volume & \\
\hline & 35.31 & cubic foot $\left(\mathrm{ft}^{3}\right)$ \\
\hline grain & Mass & \\
kilogram $(\mathrm{kg})$ & 50.00 & milligram (mg) \\
\hline
\end{tabular}




\title{
Reconnaissance Investigation of the Placer Gold Deposits in the Zarkashan Area of Interest, Ghazni Province, Afghanistan
}

\author{
By Katherine C. Malpeli, Peter G. Chirico, and Isabel H. McLoughlin
}

\section{Introduction}

Afghanistan has a wealth of mineral resources, most of which have not been explored or successfully developed since investigations were conducted by the Soviet Union in the 1960s and 1970s. In an effort to re-evaluate Afghanistan's mineral wealth, the U.S. Geological Survey (USGS) partnered with the U.S. Department of Defense Task Force for Business and Stability Operations (TFBSO) and the Afghan Geological Survey of the Afghanistan Ministry of Mines from 2009 to 2012 to conduct joint geologic activities throughout the country. Twenty-four areas of interest (AOI) were identified during the preliminary assessment, in addition to 33 subareas. These AOIs and subareas, many of which had been previously identified by Soviet and Afghan geologists, were selected by the USGS as areas warranting further investigation, and were thought to be likely to develop near-term mineral production (Peters and others, 2011a).

The focus of this study is the placer gold deposits of the Zarkashan AOI, located in Ghazni Province in southeastern Afghanistan. The AOI is 1,692 square kilometers $\left(\mathrm{km}^{2}\right)$ in area and is separated into three subareas: the Luman-Tamaki gold subarea $\left(356 \mathrm{~km}^{2}\right)$, the Bolo gold subarea $\left(313 \mathrm{~km}^{2}\right)$, and the Zarkashan mine subarea $\left(214 \mathrm{~km}^{2}\right)$ (fig. 1). These subareas have been previously prospected and have a high potential for the presence of commercial mineralized rock. In addition to containing placer gold deposits, the Zarkashan AOI also has primary copper deposits, including large porphyry coppergold, medium-size copper-gold skarn, polymetallic vein, iron skarn, and lead-zinc skarn deposits (Peters and others, 2011b).

While thorough and detailed investigations of the Zarkashan gold deposits were undertaken by Soviet and Afghan geologists, that work was conducted more than 40 years ago, and gold reserve estimates were calculated prior to the development of satellite-based remote sensing, digital terrain models (DTMs), and geographic information system (GIS) processing techniques. The goal of this study is to integrate these new technologies and techniques with previously collected sampling data, in order to reassess the placer gold deposits in the Zarkashan AOI. This report discusses the resulting estimates of gold placer targets and their potential for industrial and artisanal mining in this region.

\section{Study Area}

The Zarkashan AOI extends from northeast to southwest and is located mainly in Ghazni Province, with its southwestern corner lying in Zabul Province (fig. 1). The southeastern edge of the AOI is located $5.5 \mathrm{~km}$ northwest of the town of Muqur, and parallels the road between Kabul and Kandahar. The terrain of the region is mountainous. General elevations in the study area range from 
approximately 2,300 meters (m) to 4,000 m, resulting in topography characterized by steep slopes and narrow valleys (Chaihorsky, 2011). The arid climate, with an average of 78 millimeters (mm) of rainfall yearly, results in a predominant lack of vegetation in the study area. Valleys and northwest-facing slopes tend to be the most vegetated, and support grasslands, shrublands, forest, and croplands (Bicherone and others, 2008). The population of the AOI, estimated at approximately 82,000 people, is clustered in small pockets in the fertile valleys (Bright and others, 2007).

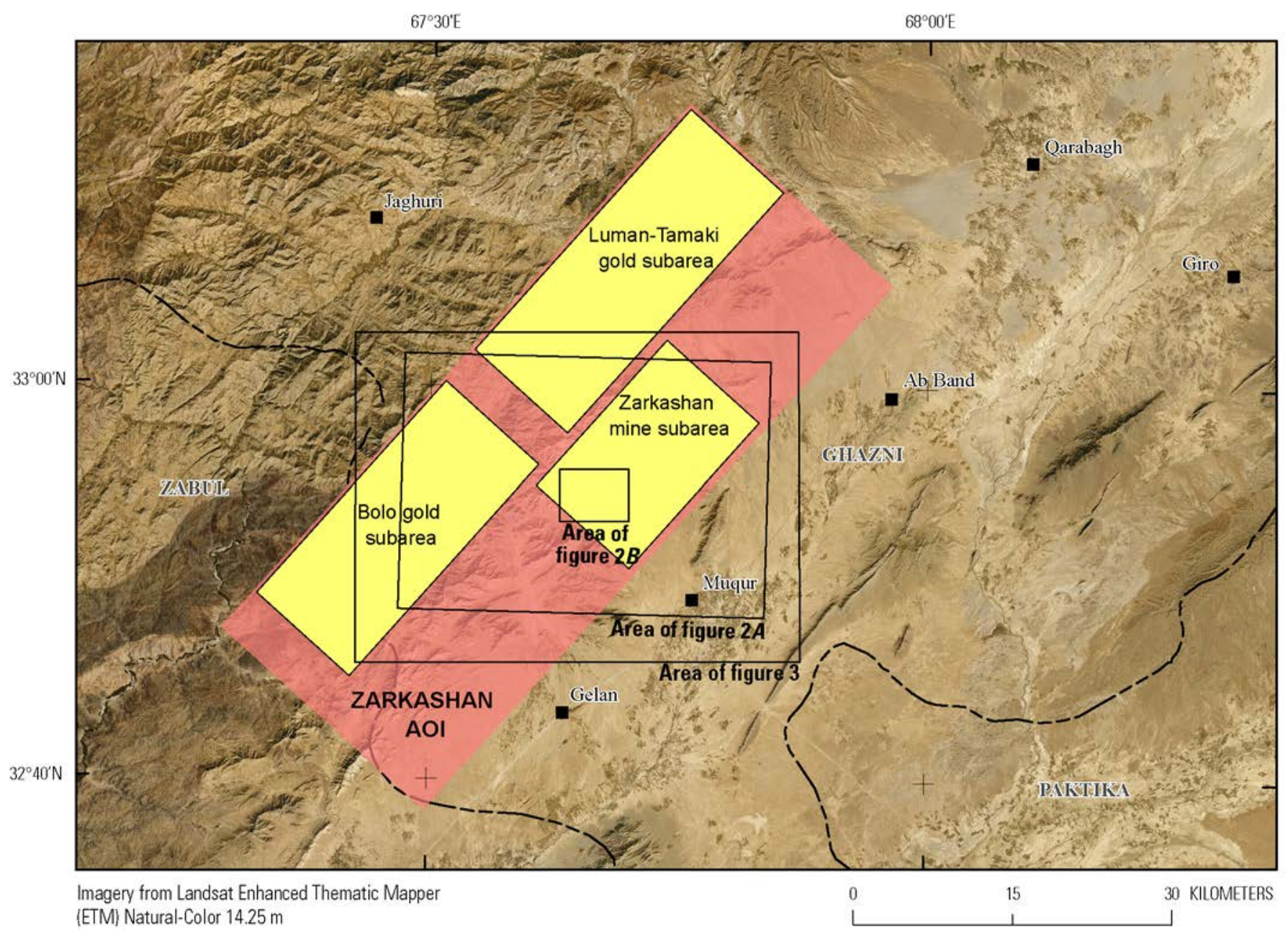

Figure 1. Map showing location of the Zarkashan AOI and the Zarkashan mine subarea, the Bolo gold subarea, and the Luman-Tamaki gold subarea.

\section{Geology}

\section{Zarkashan AOI}

The geology of the Zarkashan AOI was originally surveyed by Soviet geologists at a scale of 1:50,000 (Meshcheryakov and Sayapin, 1968). This work was updated and modified at a scale of 1:40,000 by the USGS (Peters and others, 2011c) following fieldwork and evaluations of the previous studies. The geology of the area was summarized by Peters and others (2011b), based on Peters and others (2011c) and on earlier reports by Kotov and others (1971), Meshcheryakov and Sayapin (1968a,b,c), and Doebrich and Wahl (2006). The northwestern part of the AOI consists of Late 
Proterozoic metamorphic rocks, Lower Paleozoic dolomite, limestone, and shale, and Carboniferous to Lower Permian mafic volcanic rocks, sandstone, shale, and siltstone. The central and eastern parts of the AOI consist of a vertical succession of Permian to Triassic calcareous rocks, overlain by Cretaceous limestone and sandstone (Peters and others, 2011b). The geology of the region is further summarized by Kotov and Mirzad (1968) and Abdullah and Chmyriov (1980). The geology of the central part of the Zarkashan AOI, which is the focus of this study, is summarized in figure 2.

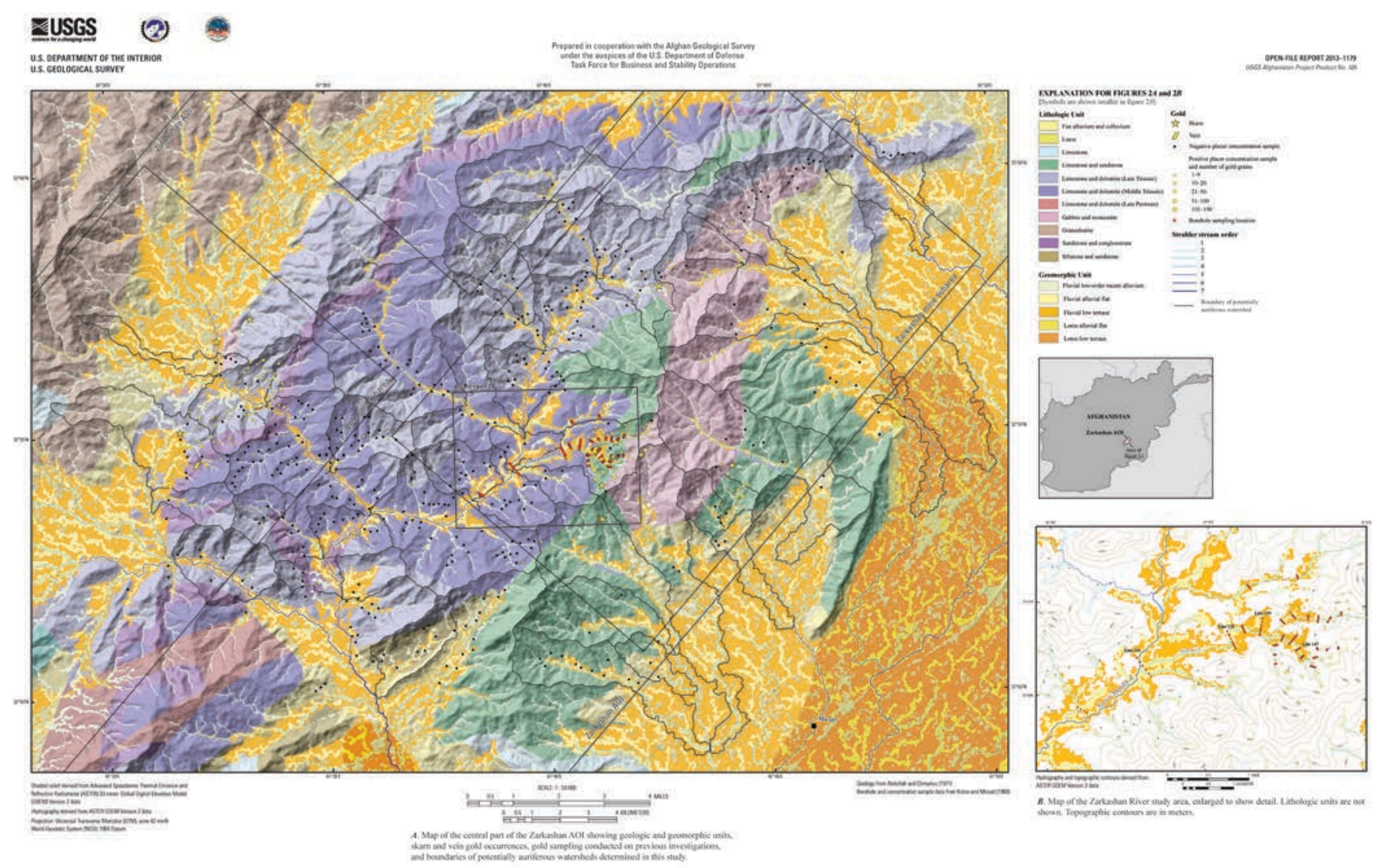

Figure 2. Maps of the central part of the Zarkashan AOI showing geologic and geomorphic units, gold occurrences, gold sampling from previous investigations, and boundaries of potentially auriferous watersheds.

\section{Zarkashan AOI Gold Deposits}

Much of our current knowledge of Afghanistan's mineral resources is the result of investigations conducted by Soviet and Afghan geologists in the 1960s and 1970s. These geologists identified two main regions having potentially economic deposits of gold: Badakhshan and Takhar Provinces in northeastern Afghanistan, and Ghazni, Zabul, and Kandahar Provinces in southeastern Afghanistan. This early work was followed by a comprehensive summary of Afghanistan's mineral resources by Abdullah and others (1980), published by the Afghan Geological Survey (AGS) and based in large part on the work done by Soviet and Afghan geologists up until 1977.

Peters and others (2007) identified the Bolo gold and Zarkashan mine subareas, both of which contain previously explored deposits, as being the most economically important gold deposits within the greater Zarkashan AOI. The Luman-Tamaki gold subarea and the remainder of the Zarkashan AOI also contain gold, but they have not been as well documented and require additional investigations to 
determine their potential. The AOI is host to both primary (in the form of skarns, veins, or porphyrys) and secondary (in the form of placers) gold deposits (fig. 2). Kotov and Mirzad (1968) summarized the location, structure, and morphology of three distinct ore zones containing skarns and veins. Skarns are located throughout the AOI, particularly along the contact zone between carbonaceous and intrusive rocks. They are situated within the intrusion or in nearby marbles and dolomites. Veins or dikes form the second type of primary deposit present in the region. These dikes are small, typically 0.5 to $1.5 \mathrm{~m}$ thick. Significant amounts of gold can also be found as a byproduct of large, relatively low-grade porphyry copper and copper-gold deposits, which require significant capital investment and mechanization to mine (Peters and others, 2011b).

The Zarkashan AOI was previously reported to be host to three types of placer deposits, which have formed from eroding veins. These are shallow deposits (less than $3 \mathrm{~m}$ deep), intermediate deposits (3-10 m deep), and deep deposits (deeper than $10 \mathrm{~m}$ ). Shallow deposits can be worked by artisans using simple hand-held tools, while intermediate deposits are more suitable for semi-mechanized mining, typically with the use of light earth-moving equipment. Deep deposits require a high level of mechanization and capital investment to mine (Peters and others, 2011b).

\section{Previous Investigations}

The Zarkashan AOI was prospected in 1967 jointly by the Soviet Technoexport and the Afghanistan Ministry of Mines and Industries. Soviet geologists first became aware of the presence of gold in the area in 1966, during prospecting activities for copper, lead, and zinc. Loose deposits of gold were found in the Zarkashan River valley that year, leading to the identification of the area as a prospective gold zone. The 1967 geological survey included detailed studies of primary ore bodies and placer deposit zones, resulting in the calculation of gold reserve estimates (Peters and others, 2011b).

The placer deposits were surveyed at a scale of 1:50,000, using two sampling methodologies. The first involved the collection of concentration samples (fig. 2A). Approximately 50 percent of the samples were taken in the Zarkashan mine subarea, 25 percent were taken within the Bolo gold subarea, and the remaining 25 percent were taken downstream of the Zarkashan mine subarea. Only four samples were taken within the Luman-Tamaki gold subarea, along its southeastern border. The distance between sampling sites was typically 200 to $500 \mathrm{~m}$, and samples were taken from small pits dug to a depth of 0.15 to $0.3 \mathrm{~m}$. In particular, valley sections considered to be more favorable for gold deposition, including headwaters and spits within channels, were chosen for sampling. In total, 712 concentration samples were collected, 279 of which were positive, and 433 of which were negative. Positive samples were those containing 1 or more grains of gold ( 1 grain $=50$ milligrams $(\mathrm{mg})$ ), while negative samples contained no gold. The second sampling methodology involved collecting from 25 linear arrays of boreholes within the Zarkashan River study area, situated along or crossing the main channel of the Zarkashan River and three of its tributaries, as well as along or crossing the Nayzer-Mandeh River and two of its tributaries (fig. 2B). Boreholes were drilled to depths ranging from 10 to $50 \mathrm{~m}$, and occasionally reached bedrock. The boreholes were then sampled at every $0.5 \mathrm{~m}$ of depth for gold. A sample of 500 milligrams per cubic meter $\left(\mathrm{mg} / \mathrm{m}^{3}\right)$ or greater was considered economically worthy of industrial mining. The geologists identified four gold-bearing seams worthy of industrial exploration, as a result of the borehole drilling. The deepest of these seams reaches 30 to $33 \mathrm{~m}$, and the shallowest is 2 to $2.5 \mathrm{~m}$ from the surface. The investigation led to the calculation of a reserve estimate for the sampled part of the Zarkashan AOI. It was estimated that 1,579 kilograms (kg) of gold are located in the Zarkashan placer deposits (Kotov and Mirzad, 1968). 


\section{Methodology}

\section{GIS Database Development}

In order to reassess the Zarkashan placer deposits we utilized a methodology integrating the collection and analysis of historical concentration and borehole sampling data, digital database development, hydrologic analysis, and geomorphic modeling through the use of a digital elevation model (DEM). First, a GIS database containing all available concentration and borehole sampling data was developed. The data were derived principally from geomorphic maps and borehole line section maps that accompany Soviet Report no. R0657 (see Meshcheryakov and Sayapin, 1968a,b,c). The location of all concentration and borehole samples and any accompanying data, such as elevation and grade, was catalogued in a GIS.

\section{Hydrologic Analysis and Geomorphic Model}

A geomorphic model was developed in order to map the active stream channel, alluvium, and terraces of the central part of the Zarkashan AOI (fig. 2B). Alluvial relief and path-distance functions were used to develop three geomorphic zones for the entire Zarkashan AOI, based on elevation: fluvial low-order recent alluvium, fluvial alluvial flats, and fluvial low terraces. The first step of creating the new geomorphic model involved the derivation of the region's hydrologic network. Because the gold located in the alluvium and terraces was deposited in the current watershed system, we infer that these current watersheds control the deposition of the alluvium and terrace gold. To map these watersheds, hydrologic features were derived using the Advanced Spaceborne Thermal Emission and Reflection Radiometer (ASTER) 30-m Global DEM. Rivers and streams (flowpaths) were derived from the DEM and ordered from 1 to 8 using the Strahler stream-order method. The logic behind the stream-ordering system developed by Strahler (1964) is that the order number is directly proportional to the size of the contributing watershed, to channel dimensions, and to stream-discharge measurements for each stream segment. These attributes were then used to model the fluvial geomorphology of each of the subbasins within the watersheds. It is important to note that gold does not occur uniformly throughout the study area; therefore, subbasins based on Strahler stream order 3 and higher containing a positive concentration of gold or a positive borehole sample (1 or more grains of gold) were identified as potentially auriferous watersheds (fig. 3). Watersheds which did not contain a positive concentration of gold were excluded from the analysis. 


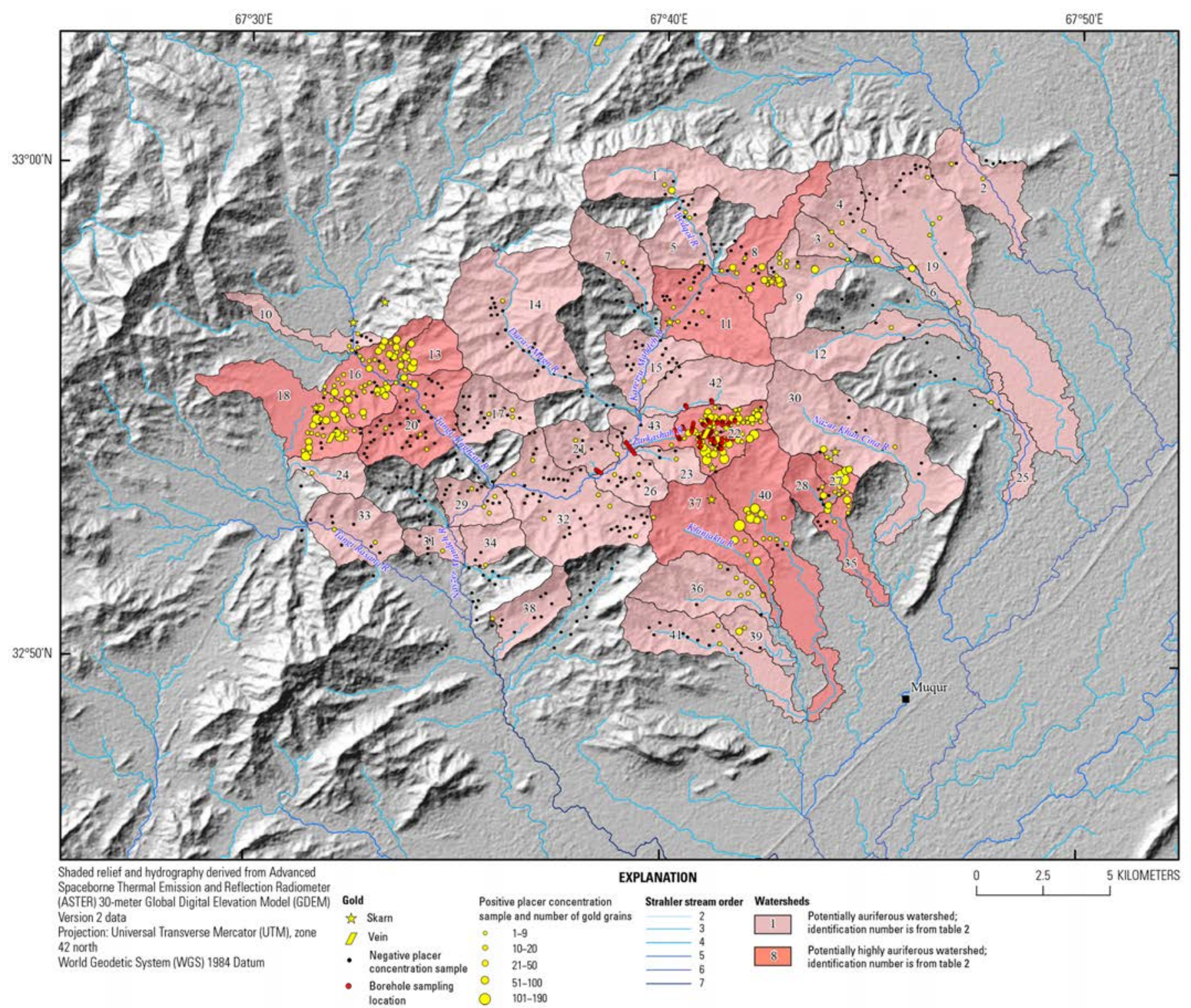

Figure 3. Map showing the potentially auriferous and potentially highly auriferous watersheds in the central part of the Zarkashan AOI.

\section{Determination of Gold-bearing Seams}

The placer gold reserves were estimated for the sampled part of the Zarkashan River, through a reinterpretation of the gold-bearing seams previously identified by the Soviets. Kotov and Mirzad (1968) defined seams as deposits containing $500 \mathrm{mg} / \mathrm{m}^{3}$ or more of gold. However, it is necessary to reexamine this cutoff grade, for several reasons. First, the price of gold has increased dramatically since sampling was carried out in 1967. In 1967, the average price of gold was \$250 per ounce (in 2011 dollars), and in 2012 it was more than $\$ 1,700$ per ounce. The price of gold therefore has increased sevenfold since the 1960s. Second, while a seam may not necessarily be rich enough to warrant industrial exploration, it may be rich enough for artisanal or small-scale exploitation, especially considering the current price of gold. Therefore, the cutoff grade employed in this study was $100 \mathrm{mg} / \mathrm{m}^{3}$.

Four borehole lines were collected by Soviet geologists along the main channel of the Zarkashan River: Lines 147 (easternmost), 139, 132, and 116 (westernmost) (fig. 2B). Between 5 and 10 boreholes 
were drilled along each line and sampled, at 0.5-m depth intervals, with the deepest borehole reaching $50 \mathrm{~m}$ in depth (line 116). With each sampled depth interval, an associated grade value was recorded. To reinterpret the Soviet-defined gold seams, the location and depth of all intervals achieving a grade of $100 \mathrm{mg} / \mathrm{m}^{3}$ or greater were recorded within each line of boreholes. Following this approach, we identified four major seams within the four lines; they are displayed in figure 4.

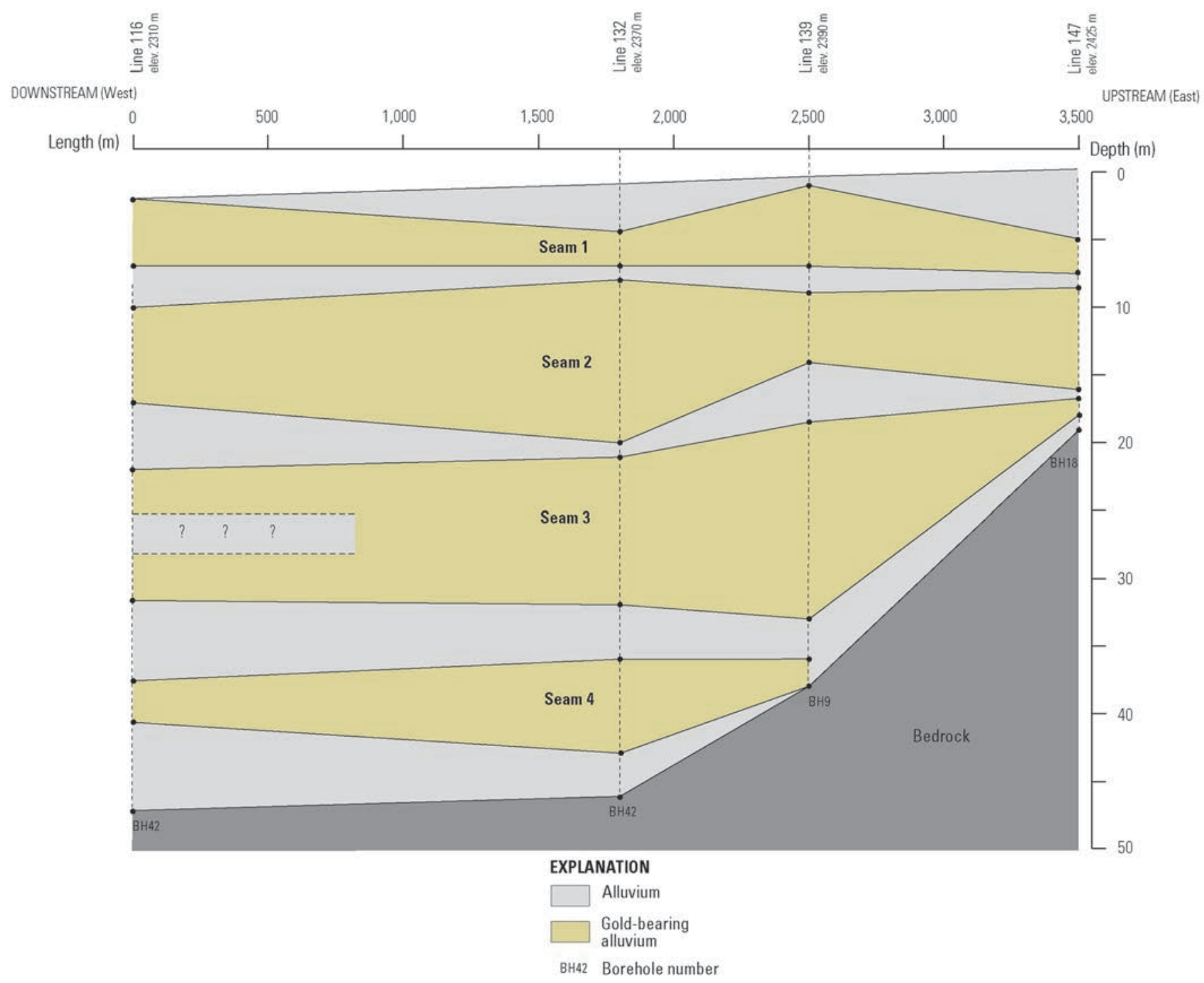

Figure 4. Profile of the four newly interpreted gold-bearing seams along the Zarkashan River.

\section{Reserve Calculations}

The resource potential was calculated using the volume and grade methodological approach, adapted from the methodology of Chirico and others (2010) for assessing alluvial diamond deposits. This approach can be expressed mathematically as $P=(V G)$, where $P$ is the estimated resource potential, $V$ is the volume of the deposit, and $G$ is the mean gravel grade of the deposit. Volume was calculated for each of the newly interpreted seams by determining the length, width, and thickness of each seam. Next, using the grades recorded for each borehole sample, an average grade was calculated 
for each seam. The volume and grade of each seam were then multiplied, and the result was totaled for the four seams to arrive at the total estimated reserve.

\section{Results}

\section{Results of the Geomorphic Model}

The geomorphic model derived in this study outlines the fluvial alluvial and fluvial low terrace deposits of the Zarkashan AOI at a much higher resolution. When compared to the DEM data, the geomorphic model maps the alluvial and terrace zones much more accurately than those that had been previously mapped. The resulting model shows a generally narrower alluvial zone than that mapped by the Soviets, and more accurately represents the narrow valleys typical of such mountainous terrain. It is within these alluvial zones in particular that there is the greatest potential for gold; therefore this model, in conjunction with the concentration and borehole samples, helps to identify zones suitable for potential further exploration.

\section{Results of the Gold Seam Reinterpretation}

Four separate gold-bearing seams, originally identified in previous studies and reinterpreted on the basis of clustering of samples having grades of $100 \mathrm{mg} / \mathrm{m}^{3}$ or greater, were located in this study. The seams increase in thickness and average grade moving downstream from line 147 to line 132, then decrease in density but remain of relatively high grade in the samples farthest downstream, along line 116. It appears therefore that line 116 represents the tail end of the seams, particularly seams 2, 3, and 4 .

\section{Estimated Reserves}

Based on the volume and grade approach, the total reserves are estimated to be approximately $3,000 \mathrm{~kg}$ of gold, located within the four seams (table 1). This number is approximately 1,500 kg greater than the Soviet estimate. The result differs in large part due to the reinterpretation of the seams based on a much lower cutoff grade of $100 \mathrm{mg} / \mathrm{m}^{3}$. Because cutoff grade is dependent in part on the price of gold, the sevenfold increase in the price of gold since the undertaking of the Soviet investigation warranted our re-evaluation of their $500 \mathrm{mg} / \mathrm{m}^{3}$ cutoff grade.

Table 1. Results of the volume and grade approach, calculated for each of the four newly interpreted gold-bearing seams.

[m, meter; $\mathrm{m}^{3}$, cubic meter; $\mathrm{mg} / \mathrm{m}^{3}$, milligram per cubic meter; kg, kilogram]

\begin{tabular}{lccccccc}
\hline Seam & $\begin{array}{c}\text { Seam length } \\
(\mathbf{m})\end{array}$ & $\begin{array}{c}\text { Seam width } \\
(\mathbf{m})\end{array}$ & $\begin{array}{c}\text { Seam } \\
\text { thickness }(\mathbf{m})\end{array}$ & $\begin{array}{c}\text { Seam volume } \\
\left(\mathbf{m}^{3}\right)\end{array}$ & $\begin{array}{c}\text { Average } \\
\text { seam grade } \\
\left(\mathbf{m g} / \mathbf{m}^{3}\right)\end{array}$ & $\begin{array}{c}\text { Seam } \\
\text { resource } \\
\text { potential }(\mathbf{k g})\end{array}$ & $\begin{array}{c}\text { Soviet } \\
\text { resource } \\
\text { potential } \\
\text { estimate }(\mathbf{k g})\end{array}$ \\
\hline 1 & 3,500 & 257.50 & 4.19 & $3,773,984.38$ & 194.84 & 735.30 & \\
2 & 3,500 & 163.75 & 7.75 & $4,441,718.75$ & 231.17 & $1,026.80$ & \\
3 & 3,500 & 126.25 & 9.38 & $4,142,578.13$ & 228.96 & 948.50 & \\
4 & 2,600 & 61.67 & 4.67 & $748,222.22$ & 514.48 & 384.94 & $1,579.00$ \\
Total & & & & & & $3,095.55$ & \\
\hline
\end{tabular}


In addition to calculating the reserve estimate for the Zarkashan River watershed (watershed number 22 in figure 3), this study identified 42 additional watersheds within the Zarkashan AOI that are potentially auriferous. These watersheds were each sampled during the 1967 Soviet and Afghan investigations of the region, and each contain at least one or more grains of gold, with the exception of watershed number 43, which was included because it is located downstream of a watershed with borehole samples and several watersheds with positive concentration samples (fig. 3, table 2). Of these auriferous watersheds, eight (including the Zarkashan River watershed) contain 100 or more grains of gold, and therefore are considered to have the greatest gold potential and are attributed as being potentially highly auriferous. In addition, four watersheds located downstream of these eight watersheds were also included in this category (fig. 3). While the four watersheds each contain several negative concentration samples, many of these samples were not collected in placer deposits because geologists were exploring for very rich primary deposits. Therefore, it is possible that these downstream placers have an increased potential for mineralization. More data on the 12 high-potential watersheds in particular is needed to determine their actual gold-yielding potential. Due to the high number of gold grains found within each of these watersheds during the 1967 investigations, future data collection and analysis within the Zarkashan AOI should target these 12 watersheds.

Table 2. Total number of gold grains sampled during previous investigations within each of the potentially auriferous and potentially highly auriferous watersheds in the central part of the Zarkashan $\mathrm{AOI}$.

\begin{tabular}{ccr}
\hline Watershed ID & $\begin{array}{c}\text { Number of } \\
\text { samples }\end{array}$ & $\begin{array}{c}\text { Total number of gold } \\
\text { grains }\end{array}$ \\
\hline 1 & 2 & 19 \\
2 & 2 & 8 \\
3 & 2 & 4 \\
4 & 4 & 21 \\
5 & 3 & 5 \\
6 & & \\
7 & 1 & 19 \\
8 & 1 & 3 \\
9 & 12 & 112 \\
10 & 8 & 76 \\
& 4 & 9 \\
11 & & \\
12 & 4 & 9 \\
13 & 1 & 1 \\
14 & 6 & 110 \\
15 & 1 & 1 \\
& 1 & 1 \\
16 & & \\
17 & 45 & 427 \\
18 & 3 & 3 \\
19 & 23 & 380 \\
20 & 5 & 13 \\
& 11 & 88
\end{tabular}


Table 2. Total number of gold grains sampled during previous investigations within each of the potentially auriferous and potentially highly auriferous watersheds in the central part of the Zarkashan AOI.—Continued

\begin{tabular}{crr}
\hline Watershed ID & $\begin{array}{c}\text { Number of } \\
\text { samples }\end{array}$ & $\begin{array}{c}\text { Total number of gold } \\
\text { grains }\end{array}$ \\
\hline 21 & 1 & 1 \\
22 & 61 & 1,019 \\
23 & 1 & 1 \\
24 & 1 & 1 \\
25 & 1 & 1 \\
& & \\
26 & 3 & 5 \\
27 & 13 & 266 \\
28 & 1 & 4 \\
29 & 4 & 4 \\
30 & 5 & 34 \\
& & \\
31 & 1 & 4 \\
32 & 6 & 7 \\
33 & 3 \\
34 & 2 & 3 \\
& 1 & 41 \\
36 & 4 & 24 \\
37 & & 299 \\
38 & 8 & 2 \\
39 & 7 & 20 \\
40 & 1 & 300 \\
41 & 2 & 2 \\
42 & 15 & 0 \\
43 & & 0 \\
\hline & 2 &
\end{tabular}

\section{Conclusion}

Through the use of a methodology that integrates digital database development, hydrologic analysis, and geomorphic modeling, four gold-bearing seams were redefined within the Zarkashan AOI, from which a new reserve estimate of $3,000 \mathrm{~kg}$ of gold was calculated. This estimate, however, covers only the central part of the Zarkashan AOI, because borehole data were available only for a part of the Zarkashan River. Based on concentration sampling, it is known that other alluvial gold deposits exist outside of the area analyzed in this study (fig. 2B). While these deposits are likely of lower grade than those within the main channel of the Zarkashan River, and possibly not economically viable for industrial-scale mining operations, it is possible that there are existing shallow placer deposits economical for small-scale artisanal miners, or intermediate placer deposits suitable for semimechanized mining activities. However, more data on the grade and distribution of gold occurrences within the remainder of the AOI, particularly within the potential watersheds highlighted in this study, is needed to identify such placers. The incorporation of such analysis would lead to a more comprehensive 
evaluation of the entire Zarkashan AOI, through the identification of gold seams that are accessible not only by industrial operations but also by semi-mechanized and artisanal operations.

\section{References Cited}

Abdullah, S., and Chmyriov, V.M., eds., 1977, Map of mineral resources of Afghanistan: Kabul, Ministry of Mines and Industries of the Democratic Republic of Afghanistan, Department of Geological and Mineral Survey, V/O Technoexport U.S.S.R., scale 1:500,000.

Abdullah, S., and Chmyriov, V.M., eds., 1980, Geologiya I poleznye iskopaemye Afganistana, Kniga 2, Poleznye iskopaemye [Geology and mineral resources of Afghanistan, book 2, mineral resources]: Moscow, Nedra, 335 p.

Bicheron, P., Defourny, P., Brockmann, C., Schouten, L., Vancutsem, C., Huc, M., Bontemps, S., Leroy, M., Achard, F., Herold, M., Ranera, F., and Arino, O., 2008, GlobCover-Products description and validation report: Accessed July 5, 2012, at http://dup.esrin.esa.int/files/p68/GLOBCOVER _Products_Description_Validation_Report_I2.1.pdf.

Bright, E.A., Coleman, P.R., King, A.L., 2007, LandScan 2006: Oak Ridge, Tenn., Oak Ridge National Laboratory.

Chaihorsky, Alex, 2011, Mukur gold fields (Zarkashan) report—Gold occurrences and deposits—Data and summaries from the 1960s to 1970s Soviet geological reports on Zarkeshan-Mukhur: U.S. Geological Survey and U.S. Department of Defense Task Force for Stability and Business Operations, $102 \mathrm{p}$.

Chirico, P.G., Malpeli, K.C., Anum, Solomon, and Phillips, E.C., 2010, Alluvial diamond resource potential and production capacity assessment of Ghana: U.S. Geological Survey Scientific Investigations Report 2010-5045, 25 p.

Doebrich, J.L., and Wahl, R.R., comps., 2006, Geologic and mineral resource map of Afghanistan, version 2: U.S. Geological Survey Open-File Report 2006-1038, one sheet, scale 1:850,000; also available at http://pubs.usgs.gov/of/2006/1038.

Kotov, A.Y., and Mirzad, S.H., 1968, Report about results of geological prospecting works at the Zarkashan deposit and placer in 1967: Kabul, Ministry of Mines and Industries of the Royal Government of Afghanistan, report no. R0657, 92 p. [Prepared by V/O Technoexport U.S.S.R. for the Ministry of Mines and Industries of the Royal Government of Afghanistan under contract no. 1378.]

Kotov, A.Y., and others, 1971, Report on prospecting and exploratory work at Zarkashan during 19671970: [Kabul] Department of Geological and Mineral Survey [unpaginated].

Meshcheryakov, E.P., and Sayapin, V.P., 1968a, Geological map of the Zarkashan-Anguri gold deposits, in Meshcheryakov, E.P., and Sayapin, V.P., Report about results of geological prospecting works at the Zarkashan deposit and placer in 1967 [and project of geological exploration for 1968]: Kabul, Ministry of Mines and Industries of the Royal Government of Afghanistan, report no. R0657, draft no. 2, one sheet, scale 1:50,000. [Prepared by V/O Technoexport U.S.S.R. for the Ministry of Mines and Industries of the Royal Government of Afghanistan under contract no. 1378.]

Meshcheryakov, E.P., and Sayapin, V.P., 1968b, Heavy concentrate sampling map of Anguri-Zarkashan gold deposits area, in Meshcheryakov, E.P., and Sayapin, V.P., Report about results of geological prospecting works at the Zarkashan deposit and placer in 1967 [and project of geological exploration for 1968]: Kabul, Ministry of Mines and Industries of the Royal Government of Afghanistan, report no. R0657, draft no. 3, one sheet, scale 1:50,000. [Prepared by V/O Technoexport U.S.S.R. for the Ministry of Mines and Industries of the Royal Government of Afghanistan under contract no. 1378.] Meshcheryakov, E.P., and Sayapin, V.P., 1968c, Report about results of geological prospecting works at the Zarkashan deposit and placer in 1967 [and project of geological exploration for 1968]: Kabul, 
Ministry of Mines and Industries of the Royal Government of Afghanistan, report no. R0657, 92 p. [Prepared by V/O Technoexport U.S.S.R. for the Ministry of Mines and Industries of the Royal Government of Afghanistan under contract no. 1378.]

Peters, S.G., Ludington, S.D., Orris, G.J., Sutphin, D.M., Bliss, J.D., and Rytuba, J.J., eds., and the U.S. Geological Survey-Afghanistan Ministry of Mines Joint Mineral Resource Assessment Team, 2007, Preliminary non-fuel mineral resource assessment of Afghanistan: U.S. Geological Survey Open-File Report 2007-1214, 810 p., 1 CD-ROM.

Peters, S.G., Kalaly, S.S., Chirico, P.G., and Hubbard, B.E., 2011a, Introduction to summaries of important areas for mineral investment and production opportunities of nonfuel minerals in Afghanistan, in Peters, S.G., King, T.V.V, Mack, T.J., Chornack, M.P., eds., and the U.S. Geological Survey Afghanistan Mineral Assessment Team, Summaries of important areas for mineral investment and production opportunities of nonfuel minerals in Afghanistan: U.S. Geological Survey Open-File Report 2011-1204, v. 1, chap. 1, p. 1-3.

Peters, S.G., Mirzad, S.H., Scott, Emily, and Hubbard, B.E., 2011b, Summary of the Zarkashan copper and gold Area of Interest, in Peters, S.G., King, T.V.V., Mack, T.J., Chornack, M.P., eds., and the U.S. Geological Survey Afghanistan Mineral Assessment Team, Summaries of important areas for mineral investment and production opportunities of nonfuel minerals in Afghanistan: U.S. Geological Survey Open-File Report 2011-1204, v. 2, chap. 15A, p. 1113-1153.

Peters, S.G., Stettner, W.R., Masonic, L.M., and Moran, T.W., comps., 2011c, Geologic map of the Zarkashan-Anguri copper and gold deposits, Ghazni Province, Afghanistan, modified from the 1968 original map compilation of E.P. Meshcheryakov and V.P. Sayapin: U.S. Geological Survey OpenFile Report 2011-1212, one sheet, scale 1:40,000.

Strahler, A.N., 1964, Quantitative geomorphology of drainage basins and channel networks, in Chow, V.T., ed., Handbook of applied hydrology: McGraw-Hill, p. 4-40. 